
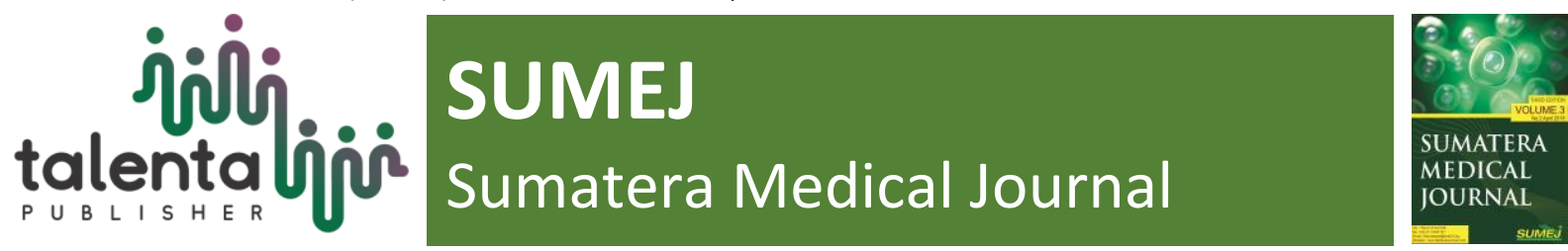

\title{
Diagnostic Accuracy of Gene X-pert MTB/RIF for Tuberculous Pleural Effusion Compared to Adenosine Deaminase (ADA) at Haji Adam Malik General Hospital Medan
}

\author{
Muhammad Zainul $A^{1^{*}}$, Fajrinur Syahrani ${ }^{2}$, Parluhutan Siagian ${ }^{3}$, Putri C \\ Eyanoer $^{4}$
}

${ }^{1,2,3,4}$ Faculty of Medicine, Universitas Sumatera Utara, Medan, North Sumatera, Indonesia.

\begin{abstract}
Indonesia is one of the few countries in the world with very high burden of tuberculosis (TB). Tubercular pleural effusion (Pleural TB) is the most common form of extra-pulmonary TB, however the remains a common clinical challenge. This research from May 2017 through September 2017 a total of 42 patients with exudative lymphocytic pleural effusions suspected to pleural tuberculosis were enrolled in this study. Adenosine deaminase (ADA) and Gene X-pert were examined from pleural fluid. Diagnosis was made clinically or based from sputum/pleural fluid culture. The result of this research showed out of all participants, 64,3\% (27/42) had ADA in positive level (>40 IU/L) and 31\% (13/24) had Gene $\mathrm{X}$-pert positive Mycobacterium $\mathrm{Tb}$. The Gene X-pert sensitivity was $40.7 \%$ with specificity $86.6 \%$, PPV and NPV were $44.8 \%$ and $57.1 \%$ respectively. Kappa Compatibility study show that Gene X-pert point was 0.227 ( $\mathrm{p}$ 0.066). The usefulness of Gene X-pert to diagnose pleural TB is limited by its poor sensitivity. Gene X-pert cannot be used as single diagnostic tool for tuberculous pleural effusion.
\end{abstract}

Keyword: Gene Xpert MTB/RIF, Tuberculous Pleural Effusion, Adenosine Deaminase

Abstrak. Indonesia adalah salah satu dari sedikit negara di dunia dengan beban tuberkulosis (TB) yang sangat tinggi. Efusi pleura tuberkular (TB pleura) adalah bentuk TB ekstrapulmoner yang paling uтum, namun tetap merupakan tantangan klinis yang uтum. Penelitian ini dari Mei 2017 hingga September 2017 total 42 pasien dengan efusi pleura limfositik eksudatif yang diduga menderita tuberculosis pleura yang terdaftar dalam penelitian ini. Adenosine deaminase (ADA) dan Gene Xpert diperiksa dari cairan pleura. Diagnosis dibuat secara klinis atau berdasarkan dari kultur cairan sputum / pleura. Hasil penelitian menunjukkan dari semua peserta, 64,3\% (27/42) memiliki ADA pada tingkat positif (> $40 \mathrm{IU} / \mathrm{L}$ ) dan 31\% (13/24) memiliki Gene Xpert positif Mycobacterium Tb. Sensitivitas Gene Xpert adalah 40,7\% dengan spesifisitas 86,6\%, PPV dan NPV masingmasing 44,8\% dan 57,1\%. Studi Kappa Compatibility menunjukkan bahwa Gene Xpert point adalah 0,227 ( $p$ 0,066). Kegunaan Gene Xpert untuk mendiagnosis TB pleura dibatasi oleh sensitivitasnya yang buruk. Gene Xpert tidak dapat digunakan sebagai alat diagnostik tunggal untuk efusi pleura TB.

Kata Kunci: Gene Xpert MTB / RIF, Efusi pleura Tuberkulosis, Adenosin Deaminase

Received [25 May 2019] | Revised [30 May 2019] | Accepted [31 May 2019]

*Corresponding author at: Faculty of Medicine, Universitas Sumatera Utara, Medan, Indonesia 


\section{Introduction}

Tuberculosis is still an infection problem worldwide. This disease can infect most of the body organs, especially lungs [1]. Pleural tuberculous is the most common form of extra-pulmonary TB and presented as pleural effusion. This medical condition remains a common medical challenge because the diagnose was difficult to enforced [2][3]. In Indonesia, most physicians had made the diagnosis based on clinical complaints, thoracic radiological examination, acid fast bacilli staining or microbiologic culture which supported to tuberculosis infection [4].

Recognizing the difficulty of establishing a diagnosis of tuberculous pleural effusion, many studies have been done to find a more optimal method of assisting the diagnosis of the disease such as pleural fluid ADA level, and Gene X-pert [5]. The aims of this study are to evaluate the accuracy of Gene X-pert and compatibility as diagnostic tools.

\section{Methodology}

A diagnostic test was done at the department of pulmonology and respiratory medicine, Haji Adam Malik General Hospital Medan, from 1st May to 30th September 2017. 45 patients with suspected tuberculous pleural effusion were enrolled. After obtaining an informed consent all patients with inclusion criteria such as; > 18 years old, thoracix Xray with pleural effusion with or without tubercular lesions and agree to performed thoracocentesis were performed detailed physical examination, routine TB examination and thoracocentensis. Pleural fluid samples were collected and performed chemical examination, cytology, microbiology culture, ADA and Gene $\mathrm{X}$-pert. All subjects also given oral antituberculosis drugs as diagnostic therapy. Four patients with abnormal coagulation status, transudative pleural effusion, non-tuberculous pleural effusion that has been diagnosed before and patients without improvement in clinical symptom or thoracic Xray after intensive phase of oral anti-tuberculosis drug were excluded.

In the descriptive analysis, quantitative variables were expressed as mean+standard deviation. Discrete variables are presented as number of cases and percentages. Sensitivity and specificity were calculated using standard procedures. All data were analysed using the SPSS statistical package.

\section{Results}

A total of 45 patients were evaluated, three samples were excluded because there is no improvement in the physical examination evaluation and thoracic Xray after intensive phase oral anti-tuberculosis drugs. Most of the patients were man (69\%) with a mean age 45.17+14.69 years. 
Table 1 Baseline Characteristic of samples

\begin{tabular}{|c|c|}
\hline Number of Subjects & 42 \\
\hline Man & $29(69 \%)$ \\
\hline Woman & $13(31 \%)$ \\
\hline Age (years) & $45.17 \pm 14.69$ \\
\hline $18-30$ & $9(21 . \overline{4} \%)$ \\
\hline $31-40$ & $8(19 \%)$ \\
\hline $41-50$ & $9(21.4 \%)$ \\
\hline $51-60$ & $6(14.3 \%)$ \\
\hline$>60$ & $10(23.8 \%)$ \\
\hline Body Mass Index & $18.30 \pm 2.61$ \\
\hline Normal & $13(31 \overline{\%})$ \\
\hline Mild thinness & $13(31 \%)$ \\
\hline Moderate thinges. & $B(19 \%)$ \\
\hline Severe thinases. & $7(16.7 \%)$ \\
\hline Preabese & $1(2.4 \%)$ \\
\hline \multicolumn{2}{|l|}{ Workplace } \\
\hline Indoor & $22(52.4 \%)$ \\
\hline Outdoor & $20(47.6 \%)$ \\
\hline \multicolumn{2}{|l|}{ Educational } \\
\hline Primary school & $6(14.3 \%)$ \\
\hline Secondary School & $14(33.3 \%)$ \\
\hline High School & $15(35.7 \%)$ \\
\hline College & $7(16.7 \%)$ \\
\hline \multicolumn{2}{|l|}{ Salary } \\
\hline$<\mathrm{Rp} \cdot 1.900 .000_{2}=$ & $23(54.8 \%)$ \\
\hline$>$ Rp.1.900.000 & $19(45.2 \%)$ \\
\hline \multicolumn{2}{|l|}{ Thoracic Xray } \\
\hline With tuberculosis infiltrative lesion & $B(19 \%)$ \\
\hline Without tuberculosis infiltrative lesion & $34(81 \%)$ \\
\hline \multicolumn{2}{|l|}{ ADA level } \\
\hline Positive $(\geq 40 \mathrm{IU} / \mathrm{L})$ & $27(64.3 \%)$ \\
\hline Negative $(<40 \mathrm{IU} / \mathrm{L})$ & $15(35.7 \%)$ \\
\hline \multicolumn{2}{|l|}{ Gene Xpert. } \\
\hline Positive & $13(31 \%)$ \\
\hline Negative & $29(69 \%)$ \\
\hline \multicolumn{2}{|l|}{ Contact with tuberculosis patients } \\
\hline Ever & $16(38.1 \%)$ \\
\hline Never & $26(61.9 \%)$ \\
\hline \multirow{2}{*}{\multicolumn{2}{|c|}{$\begin{array}{l}\text { Reference Standact } \\
\text { Sputum culture }\end{array}$}} \\
\hline & \\
\hline Positive & $13(31 \%)$ \\
\hline Negative & $29(69 \%)$ \\
\hline \multicolumn{2}{|l|}{ Pleural fluid culture } \\
\hline Rositif & $14(33.3 \%)$ \\
\hline Negative & $28(66.7 \%)$ \\
\hline \multicolumn{2}{|l|}{ Pleural fluid cytology } \\
\hline C2 benign & $38(90.5 \%)$ \\
\hline C3 atypical & $4(9.5 \%)$ \\
\hline
\end{tabular}

Only $31 \%$ samples have a normal body mass index and nutritional status with mean $18.30+2.61$ $\mathrm{kg} / \mathrm{m} 2.52 .4 \%$ subjects with indoor work places and only $16.7 \%$ with bachelor educational level. $81 \%$ samples did not have infiltrative TB lesion in their thoracic Xray. 
Table 2 Rifampicine resistant from gene Xpert examination

\begin{tabular}{ccc}
\hline Gene Xpert & n & $\%$ \\
\hline Positive Mycobacterium $\mathrm{Tb}$ Rifampicin sensitive & 11 & 26.2 \\
Positive Mycobacterium $\mathrm{Tb}$ Rifampicin resistant & 2 & 4.8 \\
Negative Mycobacterium $\mathrm{Tb}$ & 29 & 69 \\
\hline
\end{tabular}

Table 3 Result of Diagnostic Test

\begin{tabular}{lcccc}
\hline & & \multicolumn{2}{c}{ ADA } & Amount \\
\cline { 3 - 5 } Gene Xpert & & Positive & Negative & \\
& Positive & 11 & 2 & 13 \\
Amount & Negative & 16 & 13 & 29 \\
& & 27 & 15 & 42 \\
\hline
\end{tabular}

All samples were diagnosed as tuberculous pleural effusion, which $33.3 \%$ cases diagnosed based of sputum/pleural fluid culture with positive Mycobacterium $\mathrm{Tb}$ and $66.7 \%$ diagnoses based of clinical physical examination. $64.3 \%$ samples had ADA level > $40 \mathrm{IU} / \mathrm{L}$ and only $31 \%$ had a positive Mycobacterium Tb in Gene Xpert (Table 1).

Pleural fluid Gene Xpert obtained from real-time polymerase chain reaction system. This system also detected the Mycobacterium Tb deoxyribonucleic acid (DNA) which had mutation and resistant to rifampicin showed on Table 2.

Table 3 showed $2 \times 2$ table for calculation of sensitivity, specificity, positive predictive value (PPV) and negative predictive value (NPV) of Gene Xpert which were found to be $40.7 \%, 86.6 \%$, $84.6 \%$ and $44.8 \%$ respectively. Accuration was found to be $57.1 \%$ for Gene Xpert to diagnosed tuberculous pleural effusion. Kappa compatibility study was performed and true compatibility value was 0.227 ( $p$ 0.066) for Gene Xpert compared to ADA examination.

\section{Discussion}

Tuberculosis is an endemic disease in Indonesia, which ranked third place worldwide, after China and India [2], [5]. World Health Organization (WHO) data confirmed that mostly patients had a poor economic status and at young age [2]. In our study, mostly tuberculous pleural effusion patients had income below the minimum regional salary and also at $<50$ years old. In our study $66.7 \%$ patients with malnutrition status. In line with study which performed by Gupta et all, that malnutrition will convenient to tuberculosis infection [6].

Indoor workplace, especially with poor ventilation will incrases the germ in the air and facilitate the tuberculosis infection [5], [7]. Our study also proved it, which $52.4 \%$ patients in our study had indoor workplace. 
Pleural fluid ADA levels can be an easy, fast, relatively affordable and applicable diagnostic tool in diagnose pleural effusion due to tuberculosis because it has good sensitivity (95.8\%) and specificity (90.9\%) [8] [9]. In line with Kumari et all that said ADA level had high sensitivity to diagnose tuberculous pleural effusion [10], [11]. In our study, there was found $64.3 \%$ samples with ADA level positive (>40 IU/L).

The Gene Xpert MTB / RIF examination is an automatic quantitative polymerase chain reaction (PCR) technique, that able to detect Mycobacterium Tb in 2 hours and able to provide information on the successful of rifampicin therapy [12]. This examination has been validated using sputum samples and finally approved by WHO as a rapid check for positive and negative smear acid fast bacilli staining bacteria from an airway sample [2]. Similar results are also expected in diagnosing tuberculous pleural effusion with a sample of pleural fluid [13].

Although Gene Xpert can be used to enforce tuberculosis diagnose from a various fluid specimens, most studies are obtained in diagnosing tuberculous meningitis with cerebrospinal fluid samples and few studies use this examination technique to diagnose tuberculous pleural effusion [13], [14]. One study conducted by Meldau et al in 2014 of 93 subjects who were suspected of having tuberculous pleural effusion gave results that Gene Xpert had a sensitivity of $22.5 \%$ and a specificity of $98 \%$. This proves that this examination is not sensitive but specific in diagnosing tuberculous pleural effusion [13]. Equivalent results were also obtained in our study, where the sensitivity of Gene Xpert was only $40.7 \%$ but the specificity was $86.6 \%$ in diagnosing tuberculous pleural effusion. This may be happen, considering that the pleural fluid is basically asepsis and new bacteria are found in the pleural fluid after $>28$ days of infection, which in one study said after 28 days only a few germs are exposed in the pleural fluid compared to the pleural tissue [13], [15], [16]. Gene Xpert examination, which basically uses PCR technique can only detect germs based on bacterial DNA, in other words there should be germs in the sample fluids even if only slightly [2]. Its explains that there is a difference in the results on samples that are centrifuged and not centrifuged. Generally, a single examination using Gene Xpert only is not appropriate in diagnosing tuberculous pleural effusion. From this study, we know that establishing the diagnosis of tuberculous pleural effusion is not a simple matter, where confirmation is required from other diagnostic tools, regardless of clinical outcomes and diagnostic therapy.

\section{Conclusion}

The usefulness of Gene Xpert to diagnose pleural TB is limited by its poor sensitivity. Gene Xpert cannot be used as sigle diagnostic tool for tuberculous pleural effusion. 


\section{REFERENCES}

[1] W. H. Organization, Global tuberculosis control: WHO report 2010. World Health Organization, 2010.

[2] W. H. Organization, Global tuberculosis report 2015. World Health Organization, 2015.

[3] M. J. Vorster, B. W. Allwood, A. H. Diacon, and C. F. Koegelenberg, "Tuberculous pleural effusions: advances and controversies," Journal of thoracic disease, vol. 7, no. 6, p. 981, 2015.

[4] K. Kesehatan, Pedoman nasional pelayanan kedokteran tata laksana tuberkulosis. Jakarta, 2013.

[5] R. Rukmini, "Faktor-faktor yang berpengaruh terhadap kejadian TB paru dewasa di Indonesia (Analisis Data Riset Kesehatan Dasar Tahun 2010)," Buletin Penelitian Sistem Kesehatan, vol. 14, no. 4 Okt, 2011.

[6] K. B. Gupta, R. Gupta, A. Atreja, M. Verma, and S. Vishvkarma, "Tuberculosis and nutrition," Lung India: official organ of Indian Chest Society, vol. 26, no. 1, p. 9, 2009.

[7] N. McCreesh et al., "Comparison of indoor contact time data in Zambia and Western Cape, South Africa suggests targeting of interventions to reduce Mycobacterium tuberculosis transmission should be informed by local data," BMC infectious diseases, vol. 16, no. 1, p. 71, 2016.

[8] Rosfadilla. P, "Karakteristik Penderita Efusi Pleura Tuberkulosis yang Dilakukan Pemeriksaan Kadar Adenosine Deaminase Cairan Pleura," USU repository, 2016.

[9] J. Ferrer, "Pleural tuberculosis," European Respiratory Journal, vol. 10, no. 4, pp. 942947, 1997.

[10]R. P. Kumari, B. N. Reddy, and V. A. Vipula, "Role of adenosine deaminase in diagnosis of exudative type of pleural effusion," International Journal of Medical Science and Public Health, vol. 6, no. 2, pp. 286-291, 2017.

[11]A. Duran et al., "ADENOSINE DEAMINASE ACTIVITY FOR THE DIAGNOSIS OF TUBERCULOSIS PLEURAL EFFUSIONS: A DIAGNOSTIC ACCURACY STUDY," European Scientific Journal, ESJ, vol. 10, no. 33, 2014.

[12]R. W. Light, "Update on tuberculous pleural effusion," Respirology, vol. 15, no. 3, pp. 451458, 2010.

[13]R. Meldau et al., "Comparison of same day diagnostic tools including Gene Xpert and unstimulated IFN- $\gamma$ for the evaluation of pleural tuberculosis: a prospective cohort study," BMC pulmonary medicine, vol. 14, no. 1, p. 58, 2014.

[14]G. Theron et al., "Evaluation of the Xpert MTB/RIF assay for the diagnosis of pulmonary tuberculosis in a high HIV prevalence setting," American journal of respiratory and critical care medicine, vol. 184, no. 1, pp. 132-140, 2011.

[15]L. Ferreiro, E. San José, and L. Valdés, "Tuberculous pleural effusion,” Archivos de Bronconeumología (English Edition), vol. 50, no. 10, pp. 435-443, 2014.

[16]C. Charalampidis et al., "Pleura space anatomy," Journal of thoracic disease, vol. 7, no. Suppl 1, p. S27, 2015. 